\title{
Detailed insight into Arctic climatic variability during MIS 11c at Lake El'gygytgyn, NE Russia
}

\author{
H. Vogel ${ }^{1,2}$, C. Meyer-Jacob ${ }^{3}$, M. Melles ${ }^{1}$, J. Brigham-Grette ${ }^{4}$, A. A. Andreev ${ }^{1}$, V. Wennrich ${ }^{1}$, P. E. Tarasov ${ }^{5}$, and \\ P. Rosén ${ }^{6}$ \\ ${ }^{1}$ Institute of Geology and Mineralogy, University of Cologne, Zülpicher Str. 49a, 50674 Köln, Germany \\ ${ }^{2}$ Institute of Geological Sciences \& Oeschger Centre for Climate Change Research, University of Bern, Baltzerstr. 1+3, \\ 3012, Bern, Switzerland \\ ${ }^{3}$ Department of Ecology and Environmental Science, Umeå University, 90187 Umeå, Sweden \\ ${ }^{4}$ Department of Geosciences, University of Massachusetts, 611 North Pleasant Str., Amherst, MA 01003, USA \\ ${ }^{5}$ Palaeontology Branch, Institute of Geological Sciences, Free University Berlin, Malteserstr. 74-100 Haus, \\ 12249 Berlin, Germany \\ ${ }^{6}$ Climate Impacts Research Centre (CIRC), Department of Ecology and Environmental Science, Umeå University, \\ c/o Abisko Naturvetenskapliga Station, 98107 Abisko, Sweden
}

Correspondence to: H. Vogel (hendrik.vogel@geo.unibe.ch)

Received: 11 December 201 - Published in Clim. Past Discuss.: 19 December 2012

Revised: 3 May 2013 - Accepted: 10 June 2013 - Published: 15 July 2013

\begin{abstract}
Here we present a detailed multi-proxy record of the climate and environmental evolution at Lake El'gygytgyn, Far East Russian Arctic during the period 430395 ka covering the marine isotope stage (MIS) 12/11 transition and the thermal maximum of super interglacial MIS 11c. The MIS 12/11 transition at Lake El'gygytgyn is characterized by initial warming followed by a cold reversal implying similarities to the last deglaciation. The thermal maximum of MIS $11 \mathrm{c}$ is characterized by full and remarkably stable interglacial conditions with mean temperatures of the warmest month (MTWM) ranging between ca. $10-15^{\circ} \mathrm{C}$; annual precipitation (PANN) ranging between ca. $300-600 \mathrm{~mm}$; strong in-lake productivity coinciding with dark coniferous forests in the catchment; annual disintegration of the lake ice cover; and full mixis of the water column. Such conditions persisted, according to our age model, for ca. $27 \pm 8 \mathrm{kyr}$ between ca. 425-398 ka. The Lake El'gygytgyn record closely resembles the climate pattern recorded in Lake Baikal (SE Siberia) sediments and Antarctic ice cores, implying interhemispheric climate connectivity during MIS 11c.
\end{abstract}

\section{Introduction}

An understanding of past environmental changes is of particular importance to facilitate the prediction of both the magnitude and regional repercussions of future environmental changes, especially in a warming world. Future changes are expected to be especially pronounced in the polar regions, which are now experiencing observable environmental warming and change (IPCC, 2007; ACIA, 2004). The Arctic plays a major role in the global climate system by triggering complex feedback processes involving the ocean, atmosphere, cryosphere and continental land masses. It is necessary to understand the function of the Arctic in the past and in particular during past interglacials when orbital geometries were similar to today in order to more accurately predict the magnitude of future environmental changes. Marine records covering these time spans are available from the Arctic and sub-Arctic oceans (cf. McManus et al., 1999). In contrast, long continuous terrestrial records of the Arctic are scarce, with ice cores from the Greenland ice sheet only extending back to the last interglacial period (NGRIP Members, 2004).

Lake El'gygytgyn, situated in a ca. 3.6 Ma old meteorite impact crater (Layer, 2000) in north-eastern Russia contains the longest terrestrial Arctic climate records (Melles et al., 


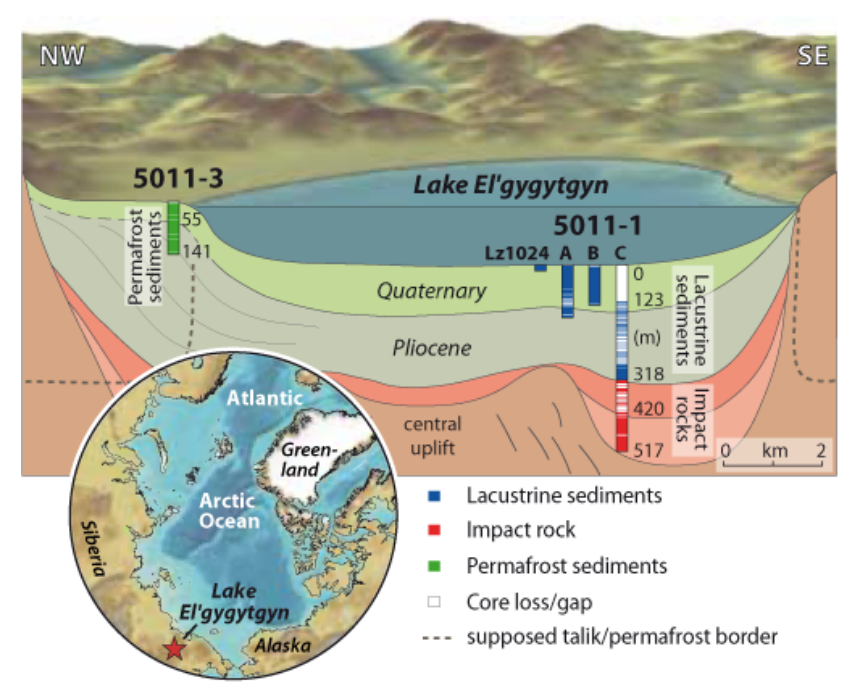

Fig. 1. Location of Lake El'gygytgyn in north-eastern Russia (inserted map) and schematic cross section of the El'gygytgyn basin stratigraphy showing the locations and recoveries of piston coring site Lz1024, ICDP Sites 5011-1, and -3 (modified after Melles et al., 2012).

2012) because the lake and its catchment were never covered by large scale Quaternary ice sheets (Glushkova and Smirnov, 2007; Melles et al., 2012). In spring 2009, the ICDP (International Continental Scientific Drilling Program) El'gygytgyn Drilling Project drilled three holes in the center of the lake (ICDP Site 5011-1A, B, and C; Fig. 1; Melles et al., 2011), following a comprehensive geophysical site survey and pilot coring (Gebhardt et al., 2006; Melles et al., 2007; Schwamborn et al., 2008; Juschus et al., 2009). A $318 \mathrm{~m}$ long composite profile of the lacustrine sediments in ICDP Site 5011-1 was constructed by splicing the bestpreserved sediment intervals in overlapping core sequences from the deep drilling and from the pre-site survey (Melles et al., 2012).

Several so-called "super interglacials" have been identified in the Quaternary sediment record from Lake El'gygytgyn (Melles et al., 2012). Among these "super interglacials", marine isotope stage (MIS) 11c and 31 appear to be the most outstanding in terms of their temperature, vegetation cover, in-lake productivity, and in the case of MIS $11 \mathrm{c}$ also duration (Melles et al., 2012). Quantitative climate reconstructions for MIS 11c and 31 at Lake El'gygytgyn imply that temperatures and annual precipitation values were up to ca. $5^{\circ} \mathrm{C}$ and ca. $300 \mathrm{~mm}$ higher if compared to the Holocene (Melles et al., 2012). Melles et al. (2012) propose perturbations of the thermohaline circulation and/or sea level changes as a consequence of West Antarctic Ice Sheet retreats as possible amplifying feedback mechanisms to explain the extreme and prolonged warming during the "super interglacials" MIS 11c and MIS 31 in the Arctic. These amplifying mechanisms are proposed because greenhouse gas and astronomical forcing alone are, according to climate simulations, not sufficient to explain the extreme conditions in the Arctic during MIS 11c and MIS 31 (Melles et al., 2012).

Because of the similarity of the earth's orbital parameters between the Holocene and MIS 11c, the latter is considered a close paleoclimatic analogue for the present interglacial (Loutre and Berger, 2000, 2003). A detailed analysis of climate variability during MIS $11 \mathrm{c}$ in the Arctic will contribute to narrowing uncertainties for future climate change and its impact in this vulnerable environment. The aims of this study are (1) to provide detailed insight into the climatic and environmental variability at Lake El'gygytgyn during MIS 11c using temporarily highly resolved datasets along with previously published low-resolution datasets (Melles et al., 2012) in order to provide a better understanding of the climatic evolution during MIS 11c in the Arctic. Moreover, (2) we aim to compare the Lake El'gygytgyn MIS 11c record with other Arctic and global climate records in order to identify common patterns and discuss possible causes of climate variability and stability during this super interglacial.

\section{Site information}

Lake El'gygytgyn $\left(67^{\circ} 30^{\prime} \mathrm{N}, 172^{\circ} 05^{\prime} \mathrm{E}\right)$ is a meteorite impact crater lake situated in the Far East Russian Arctic, approximately $100 \mathrm{~km}$ north of the Arctic Circle (Fig. 1). The impact occurred $3.58 \pm 0.04 \mathrm{Ma}$ ago (Layer, 2000) and formed a crater of $18 \mathrm{~km}$ in diameter (Fig. 1) into ignimbrites, tuffs, and basaltic andesite (Belyi and Raikevich, 1994; Nowaczyk et al., 2002). The lake itself is roughly circular with a diameter of $12 \mathrm{~km}$ (Fig. 1), covers an area of $110 \mathrm{~km}^{2}$, and has a subsurface bowl-shaped morphology with a maximum water depth of $175 \mathrm{~m}$. The permafrostdominated catchment with an area of $293 \mathrm{~km}^{2}$ is bordered by the outer rim of the impact crater structure, and is drained by 50 ephemeral streams that enter the lake at $492 \mathrm{~m}$ a.s.l. (Nolan and Brigham-Grette, 2007). The lake is drained to the Bering Sea by the Enmyvaam River at its south-eastern termination.

The climate at Lake El'gygytgyn is cold and dry with mean winter and summer temperatures ranging between -32 and $-36^{\circ} \mathrm{C}$ (January) and +4 and $+8{ }^{\circ} \mathrm{C}$ (July, August), respectively (Treshnikov, 1985), and a mean annual precipitation of $250 \mathrm{~mm}$ (Glotov and Zuev, 1995). The cold conditions are reflected in the depth of permafrost, which is modeled to be 330-360 m thick (Mottaghy et al., 2012). Although the study area belongs to the southern shrub and tundra zone, the local vegetation is rather sparse. The area is dominated by hummock and moss tundra with some prostrate willows and dwarf birch (for detailed vegetation description see Andreev et al., 2012 and references therein). The small catchment to lake surface area ratio $(<3: 1)$, in combination with cold and dry climate conditions and a thin soil and vegetation cover make Lake El'gygytgyn an oligotrophic to ultra-oligotrophic 
lake (Cremer and Wagner, 2003). With a yearly ice cover lasting from mid-October until early to mid-July, the lake is cold monomictic and thermally stratified during the icecovered season (Nolan et al., 2003).

\section{Methods}

The analytical work conducted for this study focused on the interval 19.63-17.94 m below lake floor (blf) in the composite ICDP 5011-1 core from Lake El'gygytgyn, encompassing the thermal optimum of MIS $11 \mathrm{c}$ and the transition from MIS 12. The respective interval has been spliced together from three core sections $1 \mathrm{~A}-5 \mathrm{H}-1$ (17.94-18.75 mblf), 1B4H-3 (18.75-19.02 mblf), and 1A-5H-2 (19.02-19.63 mblf).

Fourier transform infrared spectroscopy (FTIRS) has been used for high-resolution ( $2.5 \mathrm{~mm}$ intervals) reconstruction of biogenic silica (BSi) and total organic carbon (TOC). The principles of the method and analytical procedures are described in detail by Vogel et al. (2008), Rosén et al. (2011), and Meyer-Jacob et al. (2013). Concentrations of BSi and TOC in this study are based on internal calibration models in accordance with Vogel et al. (2008) and specifically developed for sediments of ICDP site 5011-1 (Meyer-Jacob et al., 2013). Sediment samples were freeze-dried and ground to a particle size $<63 \mu \mathrm{m}$ prior to the FTIR measurement. Sample material weighing $0.011 \mathrm{~g}$ was then mixed with $0.5 \mathrm{~g}$ of oven-dried spectroscopic grade potassium bromide $(\mathrm{KBr})$ (Uvasol ${ }^{\circledR}$, Merck Corp.) and subsequently homogenized using a mortar and pestle. A Bruker IFS 66v/S FTIR spectrometer (Bruker Optics Inc.) equipped with a diffuse reflectance accessory (Harrick Inc.) was used for the analysis under vacuum (4 mbar) conditions. Each sample was scanned 64 times at a resolution of $4 \mathrm{~cm}^{-1}$ (reciprocal centimeters) for the wavenumber range from 3750 to $400 \mathrm{~cm}^{-1}$ or from 2666 to $25000 \mathrm{~nm}$. The FTIR analysis was performed in a temperature-controlled laboratory $\left(25 \pm 0.2^{\circ} \mathrm{C}\right)$, in which the samples were stored at least 5 hours prior to the measurement to achieve constant measuring conditions. Baseline correction and multiplicative scatter correction (MSC) were applied to normalize the recorded FTIR spectra and to remove spectral variations caused by noise (Geladi et al., 1985; Martens and Næs, 1989). Partial least squares (PLS) regression was used to develop calibration models between FTIR spectral information and the corresponding conventionally measured concentrations of BSi and TOC.

The content of total organic carbon (TOC) in the 5011-1 core composite was determined in steps of $2 \mathrm{~cm}$ with a DimaTOC carbon analyzer (Dimatec Corp.) in aqueous suspension based upon the difference between total carbon and total inorganic carbon. Total nitrogen (TN) concentrations were measured with a Vario Micro Cube combustion CNS elemental analyzer (VARIO Co.).

Titanium (Ti), manganese ( $\mathrm{Mn})$, and iron $(\mathrm{Fe})$ count rates were determined on core halves using an X-ray fluorescence
(XRF) core scanner (ITRAX, Cox Ltd., Sweden), equipped with a Mo-tube, which was set to $30 \mathrm{kV}$ and $30 \mathrm{~mA}$. XRF scanning was performed at $2 \mathrm{~mm}$ resolution using an integration time of $10 \mathrm{~s}$ per measurement. Details of the scanning and data correction are given in Melles et al. (2012) and Wennrich et al. (2013). For a better comprehensibility, in the following, the $\mathrm{Mn} / \mathrm{Fe}$ ratio is presented as the ratio of $\mathrm{Mn}$ to Fe integrals multiplied by a factor of 1000 .

Palynological investigations have been conducted on 21 samples for the interval between 19.33-16.91 m encompassing MIS 11c (Melles et al., 2012). Details concerning the preparation method, identification of pollen and spores, percentage calculation, and diagram presentation are described in Melles et al. (2012), Andreev et al. (2012), Lozhkin and Anderson (2013). The best modern analogue (BMA) was applied to reconstruct climate variables from the palynological dataset. A complete outline on the method, datasets incorporated, and statistical evaluations are described in Melles et al. (2012 and references therein).

The development of the age model for the composite core ICDP 5011-1 followed a 3-step approach based on magnetostratigraphy and tuning of proxy records to the LR04 stack (Lisiecki and Raymo, 2005) and the summer insolation at $65^{\circ} \mathrm{N}$ (Laskar et al., 2004) and is outlined in detail in Melles et al. (2012) and Nowaczyk et al. (2013). The age model error for an individual date in the respective section is in the order of $4 \mathrm{kyr}$ (Nowaczyk et al., 2013). The temporal resolutions in the interval 19.63$17.94 \mathrm{~m}$, covering the period between $393.5-431.3 \mathrm{ka}$, are $0.025-0.122 \mathrm{kyr}$ for high-resolution $(2.5 \mathrm{~mm})$ FTIRS-BSi and FTIRS-TOC, $0.20-0.96 \mathrm{kyr}$ for low resolution $(2 \mathrm{~cm})$ TOC and TN, 0.0198-0.0974 kyr for $\mathrm{Ti}$ and $\mathrm{Mn} / \mathrm{Fe}$, and $0.6-2.9 \mathrm{kyr}$ for palynological data and pollen-derived climate variables.

\section{Results and discussion}

\subsection{Proxy interpretation}

\subsubsection{In-lake productivity indicators (BSi, TOC, TOC/TN)}

BSi in lakes is formed by silicious microfossils, mostly diatom frustules, and hence, is often used as a proxy for primary production. In Lake El'gygytgyn, diatoms are the main primary producers and well preserved in the sediment record (Snyder et al., 2013; Cherepanova et al., 2007; Cremer and Wagner, 2003). Aquatic production is primarily controlled by the availability of light, and thus, the duration of ice cover at Lake El'gygytgyn, but also the amount of nutrients delivered from the catchment and through recycling from the sediment-water interface. Nutrient supply from the catchment is dependent on the rate of chemical weathering in the active layer of the permafrost, on the formation 
of soils, and vegetation cover. Nutrient recycling from the sediment-water interface and its transport into the photic zone is promoted by full mixis of the water column during periods when the lake ice cover disintegrates. In summary, all major factors controlling primary productivity and, thus, BSi flux to the sediment at Lake El'gygytgyn are strongly tied to temperature variability.

The amount of TOC in Lake El'gygytgyn sediments also depends on lacustrine primary production, but is additionally controlled by organic matter (OM) supply from the catchment and decomposition in the lake (Melles et al., 2007, 2012). To distinguish between autochthonous versus allochthonous sources of OM, we make use of the TOC/TN ratio with values $<10$ typically indicative of in situ produced $\mathrm{OM}$ and values $>20$ typically indicative for terrestrial $\mathrm{OM}$ (Meyers and Ishiwatari, 1993).

\subsubsection{Clastic input and stratification indicators $(\mathrm{Ti}, \mathrm{Mn} / \mathrm{Fe})$}

Ti is a relatively immobile lithogenic element that occurs in a variety of mineral phases, widely independent on grain size. Therefore, it is commonly used as an indicator for allochthonous clastic sediment supply. The amounts of Fe and $\mathrm{Mn}$ are also related to clastic input, but both elements are also sensitive to redox changes in aquatic environments (cf. Davison, 1993). Mn is more soluble under reducing conditions than $\mathrm{Fe}$, making it possible to use the $\mathrm{Mn} / \mathrm{Fe}$ ratio as a paleo-redox indicator with low values typically implying more reducing conditions (cf. Davison, 1993).

\subsection{Lithology}

In close correspondence with Melles et al. (2012), the core interval between 19.63-17.94 $\mathrm{m}$ can be subdivided into three lithofacies with distinct differences in sediment structure, composition, and color.

\subsubsection{Lithofacies A}

Lithofacies A occurs in 18.02-17.94 and 19.63-19.16 mblf (Fig. 2) and is defined by the presence of fine clastic laminations on millimeter to sub-millimeter scale and by colors ranging from dark gray to black. Because the core interval investigated here comprises transitions to lithofacies B, clastic laminations are rather weakly expressed and are intercalated with more homogenous light gray to brown intervals (17.9717.94, 19.34-19.32, 19.56-19.45 mblf), which we assigned for this paper to lithofacies A. Laminae, when present, are characterized by upward grading from silt to clay. The grain size distribution is dominated by silt $(68-70 \mathrm{vol} \%)$ and clay (25-31 vol\%) with minor concentrations of sand-sized particles (0.5-5 vol\%; Francke et al., 2013). TOC concentrations $<1 \%$, BSi concentrations $<15 \%$, a TOC/TN ratio of $5-10$, Ti count rates between 1000-2100, and a $\mathrm{Mn} / \mathrm{Fe}$ ratio of $<10$ are further characteristics of lithofacies A (Fig. 2).
Based on its lithological and compositional characteristics, lithofacies A has previously been assigned to reflect pronounced glacials/stadials and perennial lake ice cover (Melles et al., 2007, 2012; Frank et al., 2012). These settings exclude mixing of the water column, which, in turn, reduces oxygen availability in the water column. The low oxygen availability and reducing conditions in the water column are expressed in overall low $\mathrm{Mn} / \mathrm{Fe}$ values and the preservation of primary laminations due to the absence of bioturbation. Low TOC and BSi concentrations and high Ti count rates (Fig. 2) point to an overall low-productivity environment. Likewise the low TOC/TN ratios indicate that OM predominantly originates from aquatic sources. Millimeter-scale laminations with upward grading are likely a result of pulsed fluvial sediment input derived from a sparsely vegetated catchment and/or exposed shelf areas during lake-level low stands. Sediment suspension plumes entering the lake basin through small moats around the margins of the ice-covered lake would explain the silt deposition, followed by clay when the inflow diminishes and the remaining suspension load settles (Melles et al., 2012).

\subsubsection{Lithofacies B}

Lithofacies B, occurring in 18.20-18.02 and 19.1419.01 mblf, appears relatively homogenous with finely dispersed vivianite crystals and lack of distinct sedimentary structures (Fig. 2). Colors gradually change through this facies between gray and light brown. Probably as a result of its transitional character between lithofacies A and C, commonly occurring greenish bands described as a distinct feature of lithofacies B by Melles et al. (2012) are lacking. The grain size distribution is dominated by silt (68-71 vol\%) and clay (25-28 vol\%) with minor concentrations of sand-sized particles (2-5 vol\%; Francke et al., 2013). TOC concentrations of $0.5-1 \%$, BSi concentrations of $15-30 \%$, a TOC/TN ratio of $5-10$, Ti count rates between $700-1300$, and a $\mathrm{Mn} / \mathrm{Fe}$ ratio of $10-15$ are further characteristics of lithofacies B (Fig. 2).

Lithofacies B is the most abundant facies in the ICDP Site 5011-1 record from Lake El'gygytgyn and is interpreted as representing varying interglacial/interstadial climate and environmental conditions (Melles et al., 2012). Gradual color changes suggest alternating sedimentary sources and/or depositional processes. The overall massive nature of the sediments along with a slightly elevated $\mathrm{Mn} / \mathrm{Fe}$ ratio indicate mixing during summer ice break up and regularly occurring oxygen replenishment of the water column, thus allowing for bioturbation (Melles et al., 2007). Elevated but variable TOC and BSi concentrations along with a TOC/TN ratio $<10$ suggests significant productivity and a predominantly autochthonous origin of OM. 


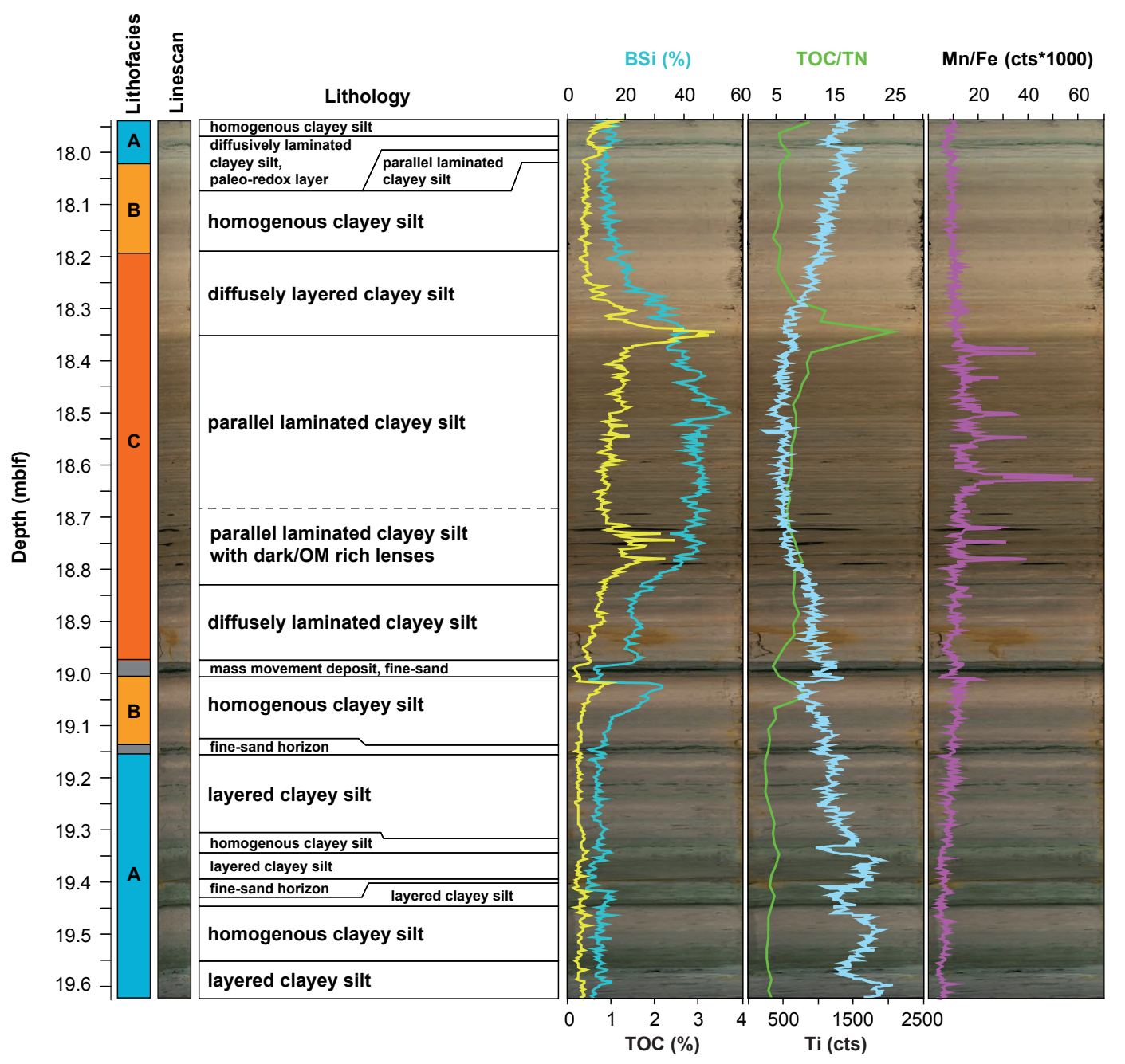

Fig. 2. Lithofacies classification, color linescan, lithological description and geochemical indicators $(\mathrm{BSi}=\mathrm{biogenic}$ silica; $\mathrm{TOC}=$ total organic carbon; $\mathrm{TN}=$ total nitrogen; $\mathrm{cts}=$ counts) underlain by stretched line scan images for the interval $17.94-19.63 \mathrm{~m}$ from the core composite of ICDP Site 5011-1 comprising the MIS 12/11 transition and MIS 11c.

\subsubsection{Lithofacies C}

Lithofacies C, occurring in $18.98-18.20$ mblf, is defined by its distinctly reddish-brown color and the presence of faint pale, millimeter- to centimeter-scale laminations (Fig. 2). Vivianite crystals occur finely dispersed and in form of discrete layered agglomerations. Laminae and bandings in lithofacies $\mathrm{C}$ are distinctly different from those observed in lithofacies A. SEM images indicate that the $1-2 \mathrm{~mm}$ thick pale bands delineating the laminations in Facies $\mathrm{C}$ reflect a transition from poorly sorted silty sediment to a nearly homogenous band of finer particles with only a few scattered siltsized clasts. The basal contact of the pale bands is typically sharp, although not planar when viewed at the grain scale. The pale bands gradually transit into the background style of sediments, which persist until the next band occurs (Melles et al., 2012). Another feature distinct for the inves- tigated core section is the occurrence of discrete millimeterscale dark bands rich in OM in 18.83-18.69 mblf. The grain size distribution is dominated by silt $(68-71 \mathrm{vol} \%)$ and clay (23.5-27 vol\%). The concentrations of sand-sized particles is slightly higher (3-6 vol\%) compared to lithofacies A and B (Francke et al., 2013). TOC concentrations range between 0.5 and $3.4 \%$ with maximum values centered at 18.34 and in 18.80-18.72 mblf (Fig. 2). BSi concentrations range between 20 and $55 \%$ with maximum values ( $>35 \%$ ) occurring in $18.79-18.34$ mblf and peak values centered at 18.49 mblf. The TOC/TN ratio shows values between $7-25$ with a distinct peak at $18.34 \mathrm{~m}$. Ti count rates are generally $<1000$ with lowest values $<500$ between 18.79-18.31 mblf (Fig. 2). The $\mathrm{Mn} / \mathrm{Fe}$ ratio shows values well above 10 with peak values exceeding 20 between 18.76 and 18.36 mblf (Fig. 2).

The reddish-brown color indicative of lithofacies $\mathrm{C}$ in combination with distinct peaks in the $\mathrm{Mn} / \mathrm{Fe}$ ratio and 
overall slightly elevated $\mathrm{Mn} / \mathrm{Fe}$ values suggests oxidation of bottom sediments by a well-ventilated water column. As for lithofacies B, this coincides with elevated summer temperatures and seasonal ice break up leading to full mixis of the water column. The origin of the banding in lithofacies $\mathrm{C}$, reflecting the lack of bioturbation, is not yet fully understood. One possibility is variable fluvial sediment supply and the absence of endobenthic fauna due to seasonal oxygen depletion of the bottom water. This could take place in wintertime, when degradation of OM takes place in a stratified water column beneath the lake ice (Melles et al., 2012). Highest TOC and BSi concentrations in combination with lowest Ti count rates imply strongest productivity, inhibited flux and/or dilution of clastic matter by biogenic components during deposition of lithofacies C. Higher TOC/TN values compared to lithofacies A and B point to an increased contribution of terrestrial sources of OM. However, with the exception of the maximum centered at 18.34 mblf, it can be assumed that OM in lithofacies $\mathrm{C}$ is primarily of aquatic origin.

\subsubsection{Mass movement deposits}

Mass movement deposits occurring at ca. 19.01-18.98 and 19.16-19.14 mblf are indicated by an apparent sharp base and an upward grading from fine sand to silt. These deposits, according to the classification of Kukkonen et al. (2013), originate from turbidity currents. Nevertheless, erosion of previously deposited sediments is thought to be minimal (Melles et al., 2007, 2012). In difference to all mass movement deposits thicker then $5 \mathrm{~cm}$, these two thin layers were not omitted from the core composite of ICDP Site 5011-1 (Melles et al., 2012).

\section{Interpretation}

\subsection{Climate and environmental evolution at Lake El'gygytgyn during MIS 11c}

This section aims at documenting climate and environmental change at Lake El'gygytgyn during the period ca. 430$395 \mathrm{ka}$ covering the thermal optimum of MIS 11 (424$374 \mathrm{ka}$ ) in light of detailed lithological, high-resolution FTIRS-BSi and FTIRS-TOC, and element intensity datasets original to this study as well as previously published element intensity data, results of pollen analysis (Lozhkin and Anderson, 2013), and pollen-based climate reconstructions (Melles et al., 2012).

Overall low BSi and TOC concentrations along with a lithology characterized by lithofacies A sediment types, high $\mathrm{Ti}$ count rates, and a low $\mathrm{Mn} / \mathrm{Fe}$ ratio point to a low productivity environment and perennial ice coverage on the lake for the period ca. 430-425 ka (Fig. 3a, b, d, e). Pollen assemblages imply a gradual replacement of herb-dominated Arctic tundra and the establishment of forest-tundra and northern larch taiga environments with alder and birch shrubs.
Pollen-based climate reconstructions suggest that mean temperatures of the warmest month (MTWM; Fig. 3i) and annual precipitation (PANN; Fig. 3k) gradually increase from ca. 4$12^{\circ} \mathrm{C}$ and ca. $200-400 \mathrm{~mm}$, respectively, between ca. 430 $425 \mathrm{ka}$ (Fig. 3i, k; Melles et al., 2012). Emplacement of forest tundra probably started in sheltered south-exposed areas of the crater and its surroundings and did not cover the whole catchment area. A patch like vegetation pattern and soil stabilization only in confined areas is supported by relatively high Ti count rates indicating high fluxes of allochthonous clastic matter.

BSi and TOC concentrations show a significant increase between 425-424 ka marking the beginning of enhanced inlake productivity at Lake El'gygytgyn at the beginning of MIS 11c (Fig. 3a, b). Deposition of the light brown, homogeneous lithofacies B (Figs. 2,3) along with a slight increase in the $\mathrm{Mn} / \mathrm{Fe}$ ratio (Fig. 3e) imply annual mixis and a welloxygenated water column. The increase in in-lake productivity is matched by a concomitant increase in spruce pollen percentages and a decrease in grass and other herb pollen percentages (Fig. 3; Melles et al., 2012; Lozhkin and Anderson, 2013). A somewhat stronger flux of OM and a suppressed flux of allochthonous clastic matter resulting from a denser vegetation cover in the confined crater catchment is expressed by a slight increase of the TOC/TN ratio and a decrease in Ti count rates, respectively (Fig. 3c, d). Biomarkers indicative of terrestrial OM do not, however, show an observable contemporaneous increase (D'Anjou et al., 2013). In close correspondence to the observed changes in in-lake productivity and vegetation, MTWM increases to ca. $15^{\circ} \mathrm{C}$ and PANN to $>600 \mathrm{~mm}$ (Melles et al., 2012; Fig. 3i, k), thus completing a coherent picture of a significant climate amelioration in a time span of only ca. 1 kyr at Lake El'gygytgyn. Following the climate amelioration between ca. 425-424 ka, a setback to a slightly less productive environment and a somewhat colder and drier climate between ca. 424-420 ka is indicated by a decrease in in-lake productivity indicators, spruce pollen contents, fluxes of terrestrial OM, MTWM, PANN, and an increase in the flux of allochthonous clastic matter (Fig. 3).

A significant increase in in-lake productivity indicators, tree and shrub pollen contents, MTWM, and PANN at ca. 420-418.5 ka marks the beginning of relatively stable, long-lasting optimum climate conditions of MIS 11c at Lake El'gygytgyn, which lasted from ca. 418.5 to ca. $402 \mathrm{ka}$ (Fig. 3). BSi shows only minor fluctuations and reaches maximum concentrations of more than $50 \%$ at ca. 418.5$402 \mathrm{ka}$ (Fig. 3a). These values are unmatched in the remaining record from ICDP site 5011-1 (Meyer-Jacob et al., this issue) making diatom frustules the main sediment component (Figs. 2, 3a). This in combination with a high diatom diversity (Snyder et al., 2013), high TOC concentrations, a high $\mathrm{Mn} / \mathrm{Fe}$ ratio, low Ti count rates, and a lithology characterized by brown oxidized sediments (Figs. 2,3) indicates a very productive lake environment with annual ice break up 


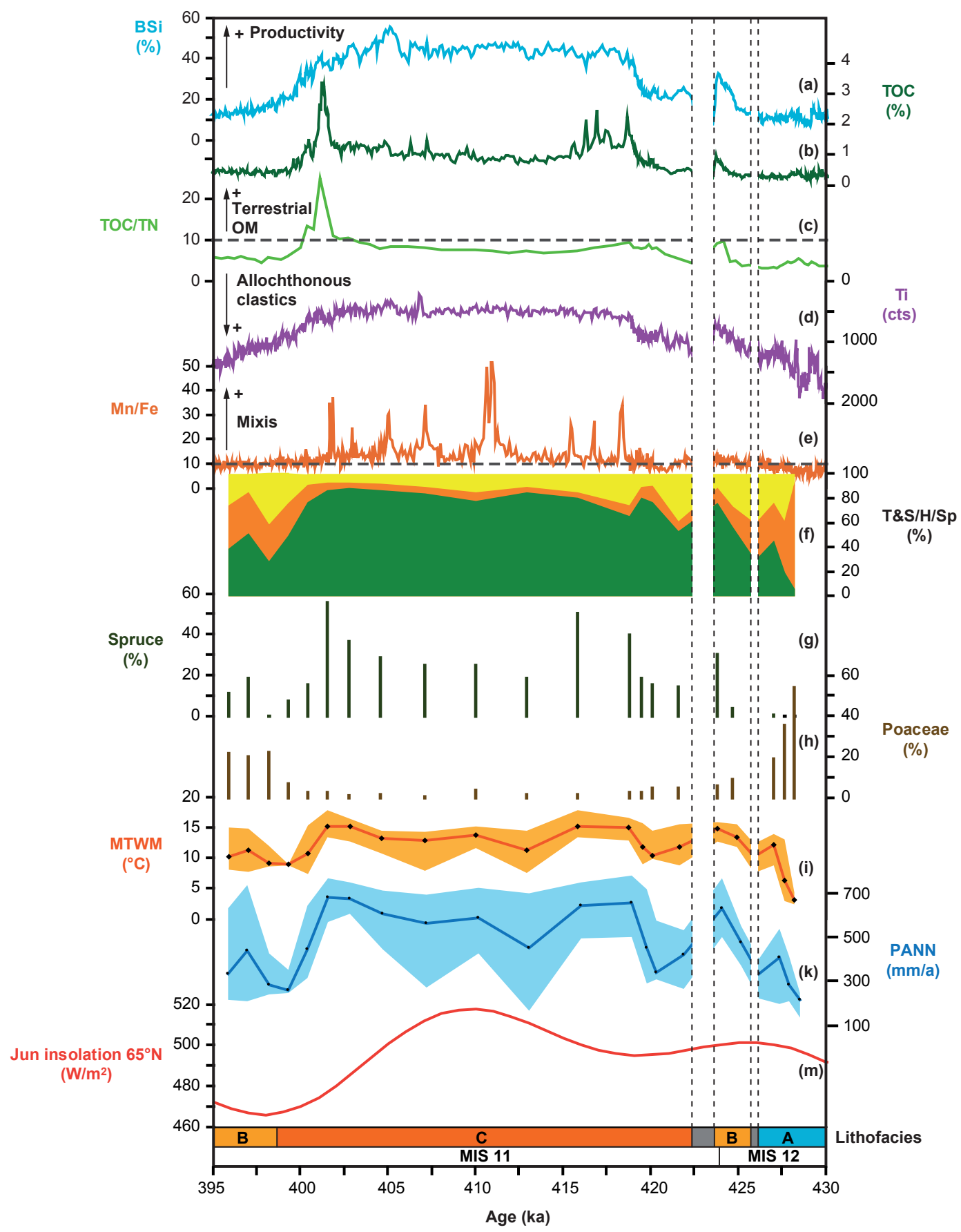

Fig. 3. Indicators for climate and environmental change at Lake El'gygytgyn between 430-395 ka covering the MIS 12/11 transition and full interglacial conditions of MIS 11c. (a) FTIRS inferred biogenic silica (BSi) concentrations; (b) FTIRS inferred total organic carbon (TOC) concentrations; (c) total organic carbon/total nitrogen (TOC/TN) ratio; (d) Ti counts (cts); (e) Mn/Fe ratio (Melles et al., 2012); (f) percentages of trees $(\mathrm{T})$ and shrubs $(\mathrm{S}$; green shading), herbs $(\mathrm{H}$; orange shading), and spores (Sp; yellow shading). The calculation of the group percentages is based on the total sum of pollen and spores taken as $100 \%$ (Melles et al., 2012): (g) spruce (Picea) pollen percentages calculated upon the terrestrial pollen sum taken as $100 \%$ (Melles et al., 2012), (h) grass (Poaceae) pollen percentages calculated upon the terrestrial pollen sum taken as $100 \%$ (Melles et al., 2012); (i) mean temperature of the warmest month with orange shaded error range (MTWM; Melles et al., 2012); (k) annual precipitation with blue shaded error range (PANN; Melles et al., 2012); (m) summer (June) insolation at $65^{\circ} \mathrm{N}$ (Laskar et al., 2004), lithofacies, and MIS 12/11 boundary according to Lisiecki and Raymo (2005). Vertical dashed lines mark the boundaries of disturbed sections. The age model error for an individual date in the respective interval from Lake El'gygytgyn is in the order of 4 kyrs (Nowaczyk et al., 2013). 
and full mixis of the water column. High in-lake productivity during this period is a result of mild and moist climate conditions, as indicated by MTWM ranging between ca. $12-15^{\circ} \mathrm{C}$ and PANN ranging between ca. $450-700 \mathrm{~mm}$ (Melles at al., 2012; Fig. 3i, k). Nutrient fluxes from the catchment were likely promoted by the development of soils as a result of the emplacement of dark coniferous forests with high amounts of spruce and interspersed patches of Sphagnum bogs (Fig. 3g; Melles et al., 2012). Higher fluxes of catchment-derived nutrients are also indicated by a slightly higher TOC/TN ratio (Fig. 3c) and a significant increase in terrestrial biomarker concentrations (D'Anjou et al., 2013).

Despite the coherent picture of stable optimum climate and environmental conditions between ca. 418.5-402 ka, subtle variability in the proxy and lithological record point to subtle environmental variability. Coinciding peaks in MTWM, PANN, spruce pollen percentage, and TOC (Fig. 3b, g, i, k), together with the occurrence of OM-rich lenses in the sediment record between 418-415.5 ka (Fig. 2), may be indicative for a relatively warm and wet phase. Interestingly, the occurrence of OM-rich lenses and high TOC concentrations cannot be explained by a significant increase in $\mathrm{BSi} /$ in-lake productivity or fluxes of terrestrially derived OM thus arguing against a significantly warmer and wetter phase. Consequently, elevated TOC concentrations and the occurrence of OM rich lenses may result from a relatively strong in-lake productivity during warm summers and enhanced preservation of OM due to prolonged oxygen depletion in the water column. Prolonged oxygen depletion in the water column may be caused by a longer duration of ice coverage at Lake El'gygytgyn as a result of reduced summer insolation (Fig. 3m).

A gradual decrease in in-lake productivity indicators, tree and shrub pollen contents, MTWM, and PANN, and a gradual increase of allochthonous clastic matter commencing between ca. 402-398 ka points to a gradual climate deterioration over a period of ca. $4 \mathrm{kyr}$ (Fig. 3). A remarkable feature during this phase is the concomitant occurrence of peak TOC and TOC/TN values centered at ca. $401 \mathrm{ka}$, reaching up to $3.4 \%$ and 25 , respectively (Fig. 3b, c). These peak values point to a significant input of terrestrial OM, which can be interpreted as a result of (1) enhanced soil erosion or (2) increased input of litter from trees surrounding the lake. Increased spruce pollen percentages in combination with the lack of terrestrial plant macrofossils or other lithological peculiarities and relatively low terrestrial biomarker concentrations (D'Anjou et al., 2013) argue against significant soil erosion and favor the increased input of litter as an explanation. From $398 \mathrm{ka}$ all proxies and pollen spectra indicative for open grass-sedge habitats (Melles et al., 2012; Fig. 3) suggest a return to glacial/stadial conditions at Lake El'gygytgyn comparable to those at the MIS 12/11 transition (Fig. 3).

\subsection{The MIS 11c climate record from Lake El'gygytgyn viewed in a global context}

Comparison of the Lake El'gygytgyn climate record with other globally distributed climate records and the northern $\left(65^{\circ} \mathrm{N}\right)$ and southern $\left(65^{\circ} \mathrm{S}\right)$ hemisphere summer insolation (Laskar et al., 2004) suggests intriguing similarities but also differences with respect to the duration, overall stability, and short-term climate fluctuations during MIS 11c (Fig. 4).

Between ca. 425-398 ka, the investigated proxies and lithological peculiarities indicate high productivity, annual ice break up and full mixis of the water column, and vegetation characterized by dark coniferous forests. This suggests, taking the proposed age model error of $4 \mathrm{kyr}$ for an individual date (Nowaczyk et al., 2013) into account, that full interglacial conditions persisted for ca. $27 \pm 8 \mathrm{kyr}$ at Lake El'gygytgyn during MIS 11c (Figs. 3, 4). The beginning and duration of these conditions compares well with the terrestrial records from Lake Baikal (ca. 424-396 ka; Prokopenko et al., 2010) and the EPICA Dome C (EDC) ice core record (ca. 424-394 ka; EPICA community members, 2004). The slightly shorter duration inferred for Lake El'gygytgyn may be a result of age-model discrepancies between the records, which can easily be in the order of several kyrs (EPICA community members, 2004; Prokopenko et al., 2010; Pol et al., 2011; Nowaczyk et al., 2013). The long duration of full interglacial conditions during MIS 11c is commonly explained as being a result of low-amplitude insolation variations and long-lasting high $\mathrm{CO}_{2}$ concentrations (Loutre and Berger, 2003; Raynaud et al., 2005; Fig. 4). These conditions prevented Northern Hemisphere ice sheets from growing and are thought to have led to a partial or even complete disintegration of the Greenland (GIS) and West Antarctic Ice Sheets (WAIS; Willerslev et al., 2007; Raymo and Mitrovica, 2012), further promoting interglacial conditions through positive albedo feedbacks.

The indicated long-term stability of climate and environmental conditions during MIS 11c at Lake El'gygytgyn is another striking feature, which is also apparent at Lake Baikal (Karabanov et al., 2003; Prokopenko et al., 2010) and in the EDC ice core record (EPICA community members, 2004; Pol et al., 2011). In contrast, sea surface temperature (SST) records from the Atlantic and Pacific oceans show a somewhat stronger internal variability during MIS $11 \mathrm{c}$ (Fig. 4e, f, g, h, i; Oppo et al., 1998; Martrat et al., 2007; Schaefer et al., 2005; Kandiano and Bauch, 2007; Li et al., 2011). Most of these differences can easily be explained by substantial differences of the applied age models, with individual errors on the order of several kyrs. However, contrasting internal variabilities between high latitude terrestrial and mid-latitude marine sites could in part also be related to atmospheric and ocean circulation patterns specific to these types of interglacial conditions (Melles et al., 2012). Based on the coincidence of super interglacial conditions documented in the Lake El'gygytgyn record with a diminished WAIS, and open 


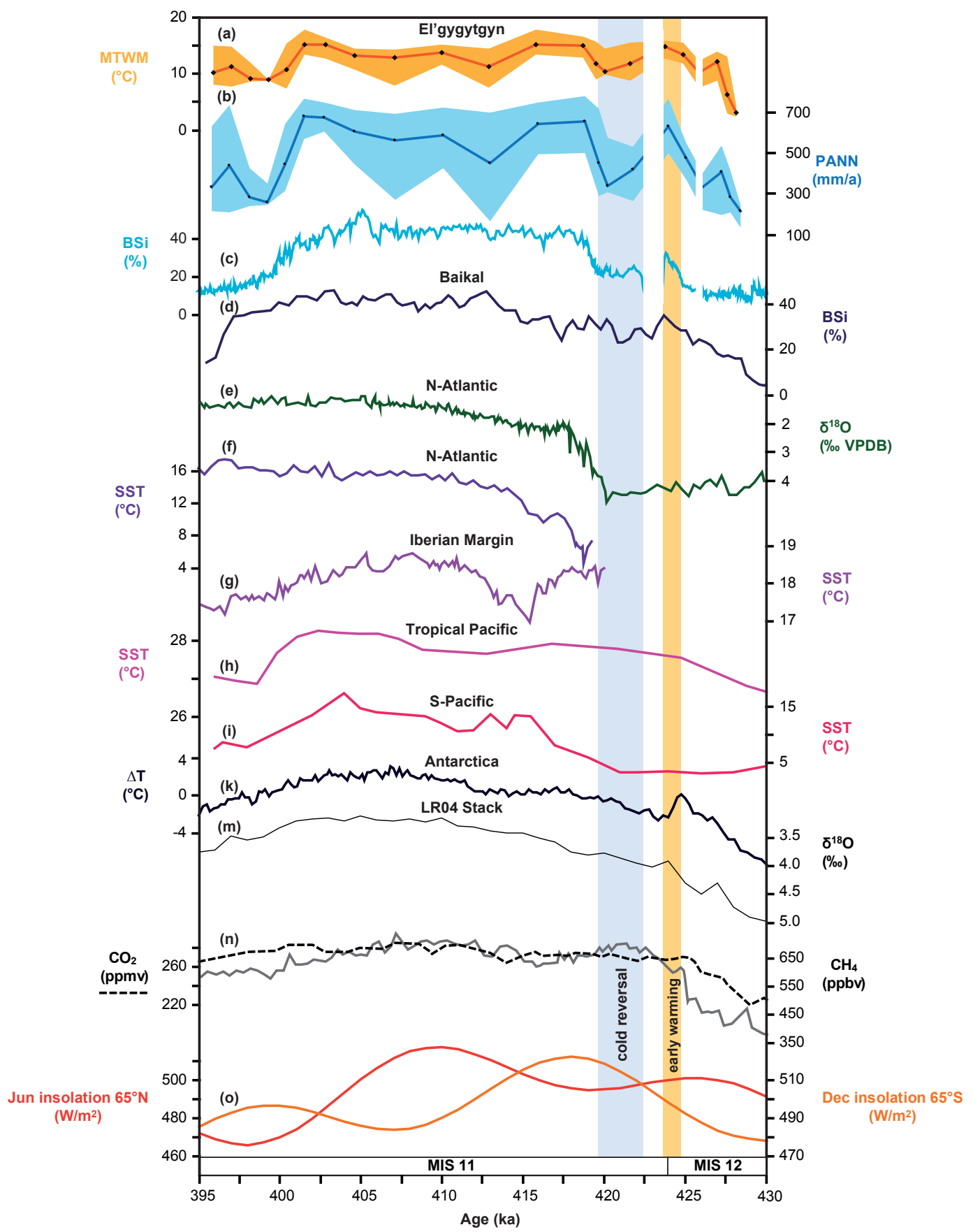

Fig. 4. Comparison of Lake El'gygytgyn climate indicators with other globally distributed climate records between 430-395 ka. (a) mean temperature of the warmest month with orange shaded error range (MTWM) from Lake El'gygytgyn (Melles et al., 2012); (b) annual precipitation with blue shaded error range (PANN) from Lake El'gygytgyn (Melles et al., 2012); (c) FTIRS inferred biogenic silica (BSi) concentrations from Lake El'gygytgyn; (d) biogenic silica (BSi) concentrations from Lake Baikal (Prokopenko et al., 2006); (e) oxygen isotopes of planktic foraminifera (right-coiling N. pachyderma) from the N. Atlantic (ODP site 980; Oppo et al., 1998); (f) sea surface temperatures (SST) from the N. Atlantic (Kandiano and Bauch, 2007); (g) SSTs from the Iberian Margin/N. Atlantic (Martrat et al., 2007); (h) SSTs from the tropical Pacific (Li et al., 2011); (i) SSTs from the S. Pacific (Schaefer et al., 2005); (k) temperature anomaly relative to the mean of the last $1000 \mathrm{yr}(\Delta \mathrm{T})$ from the EPICA Dome C ice core record (Jouzel et al., 2007); (m) LR04 benthic oxygen isotope stack (Lisiecki and Raymo, 2005); (n) $\mathrm{CO}_{2}$ (Siegenthaler et al., 2005) and $\mathrm{CH}_{4}$ (Loulergue et al., 2008) concentrations from the EPICA Dome $\mathrm{C}$ ice core record; (o) summer insolation at $65^{\circ} \mathrm{N}$ (June) and $65^{\circ} \mathrm{S}$ (December; Laskar et al., 2004). Orange shading highlights the early warming and blue shading the cold reversal at Lake El'gygytgyn. The age model error for an individual date in the respective interval from Lake El'gygytgyn is in the order of 4 kyrs (Nowaczyk et al., 2013). 
water conditions in the Ross embayment, Melles et al. (2012) suggest a reduction of Antarctic bottom water (AABW) formation and upwelling in the northern North Pacific during MIS 11c. In consequence, surface-water stratification in the northern North Pacific during MIS 11c may have resulted in higher SSTs, raising air temperatures and precipitation rates over adjacent land masses via effects on the dominant pressure patterns (Siberian High and Aleutian Low; Melles et al., 2012). Interestingly, a steep SST gradient from north to south as a result of continued melting of ice sheets, surfacewater freshening, and concomitant effects on ocean and atmospheric circulation has also been suggested for the North Atlantic during MIS 11c (Kandiano et al., 2012 and references therein). However, in order to untangle the underlying mechanisms behind the observed differences at marine and terrestrial sites more detailed studies incorporating terrestrial and marine records from additional globally distributed sites are required.

Subtle deviations from the overall stable climate and environmental conditions at Lake El'gygytgyn are centered between ca. 425-424 and ca. 424-420 ka (Figs. 3, 4). The initial warming between ca. 425-424 ka followed by a cold reversal between ca. 424-420 ka appears to be matched by a similar early MIS $11 \mathrm{c}$ pattern in the Lake Baikal BSi record (Fig. 4d; Karabanov et al., 2003) and the EDC $\Delta \mathrm{T}$ record (Fig. 4k; EPICA community members, 2004). An early warming followed by a cold reversal in the EPICA Dome $\mathrm{C} \Delta \mathrm{T}$ record (Fig. $4 \mathrm{k}$ ) has been proposed to be a possible MIS 11c analogue for the Antarctic cold reversal (ACR) or the short-termed cold reversal at around $8 \mathrm{ka}$ (EPICA community members, 2004). The similar pattern of these climate repercussions and their timing within the early part of the interglacial at Lake El'gygytgyn, Lake Baikal and Antarctic ice cores (Fig. 4) could thus be the result of a similar underlying mechanism during the MIS 12/11 transition as has been proposed for the last deglaciation (Blunier et al., 1997). However, the error of the respective age models does not allow for correlation of the observed events or estimates on their duration.

A gradual climate deterioration commencing at ca. $400 \mathrm{ka}$ associated with a subtle decrease in summer insolation (Laskar et al., 2004) and slow ice build up on the Northern Hemisphere landmasses (Imbrie et al., 1984, 1993; Lisiecki and Raymo, 2005) is a coherent feature visible in nearly all marine and terrestrial records during MIS 11c (Fig. 4). In contrast, other interglacials, for example MIS 5e, show a more rapid climate deterioration towards their end, at Lake El'gygytgyn (Cunningham et al., 2013) as well as at other globally distributed sites (cf. Sirocko et al., 2005).

\section{Conclusions}

Detailed evaluation of lithological, geochemical, and palynological data provide further evidence for the exceptional character of the MIS 11c "super interglacial" at Lake El'gygytgyn and in the Arctic. Its climate stability, duration, and a gradual climate deterioration towards the end in combination with its outstanding appearance as one of the warmest interglacials in the Lake El'gygytgyn record during the entire Quaternary (Melles et al., 2012) make MIS 11c unique. The close correspondence of the climate signal recorded at Lake El'gygytgyn with other globally distributed sites emphasize the value of the Lake El'gygytgyn record as the most promising archive for the long-term climate history in the terrestrial Arctic.

Despite the overall stability of climate and environmental conditions at Lake El'gygytgyn, subtle deviations from the average have been identified for the periods 425-424 (warming), 424-420 (cooling). Correlation of these climate swings at Lake El'gygytgyn to other globally distributed sites is hampered because of the apparent large errors of individual age-models. It can, however, be noted that similar climate repercussions consisting of an early MIS $11 \mathrm{c}$ warming that is followed by a cooling event are also evident in climate records from Lake Baikal and Antarctica. In order to better define the nature of these relatively short-termed climate variations it would be valuable to conduct more detailed high-resolution palynological investigations on the MIS 11c sediment succession from Lake El'gygytgyn.

Acknowledgements. "Funding for the drilling operations at Lake El'gygytgyn was provided by the International Continental Scientific Drilling Program (ICDP), the US National Science Foundation (NSF), the German Federal Ministry of Education and Research (BMBF), Alfred Wegener Institute (AWI) and GeoForschungsZentrum Potsdam (GFZ), the Russian Academy of Sciences Far East Branch (RAS FEB), the Russian Foundation for Basic Research (RFBR), and the Austrian Federal Ministry of Science and Research (BMWF). The Russian GLAD 800 drilling system was developed and operated by DOSECC Inc. and LacCore, at the University of Minnesota, handled core curation. This study on the core material was funded by the BMBF (grant no. 03G0642A) and the German Research Foundation (DFG, grant no. ME 1169/21). Funding for the FTIRS research was provided by the Swedish Research Council (VR), FORMAS, and the Kempe Foundation. We are grateful to D. Raynaud one anonymous reviewer and the editor D. D. Rousseau for valuable comments and suggestions that substantially improved the manuscript as well as Nicole Mantke and various students (University of Cologne) for their competent help in core processing.

Edited by: D.-D. Rousseau 


\section{References}

ACIA: Impacts of a Warming Arctic. Cambridge University Press, 140, 2004.

Andreev, A. A., Morozova, E., Fedorov, G., Schirrmeister, L., Bobrov, A. A., Kienast, F., and Schwamborn, G.: Vegetation history of central Chukotka deduced from permafrost paleoenvironmental records of the El'gygytgyn Impact Crater, Clim. Past, 8, 1287-1300, doi:10.5194/cp-8-1287-2012, 2012.

Belyi, V. F. and Raikevich, M. I.: The El'gygytgyn lake basin (geological structure, morphostructure, impactites, problems of investigation and preservation of nature), NEISRI FEB RAS, Magadan, 27 pp., 1994.

Blunier, T., Schwander, J., Stauffer, B., Stocker, T., Dällenbach, A., Indermühle, A., Tschumi, J., Chappellaz, J., Raynaud, D., and Barnola, J.-M.: Timing of the Antarctic Cold Reversal and the atmospheric $\mathrm{CO}_{2}$ increase with respect to the Younger Dryas event, Geophys. Res. Lett., 24, 2683-2686, 1997.

Cherepanova, M. V., Snyder, J. A., and Brigham-Grette, J.: Diatom stratigraphy of the last $250 \mathrm{ka}$ at Lake El'gygytgyn, northeast Siberia, J. Paleolimnol., 37, 155-162, 2007.

Cremer, H. and Wagner, B.: The diatom flora in the ultraoligotrophic Lake EI'gygytgyn, Chukotka, Polar Biol., 26, 105$114,2003$.

Cunningham, L., Vogel, H., Nowaczyk, N. R., Wennrich, V., Juschus, O., Persson, P., and Rosén, P.: Climatic variability during the last interglacial inferred from geochemical proxies in the Lake El'gygytgyn sediment record, Palaeogorgr. Palaeoclimat. Palaeoecol., doi:10.1016/j.palaeo.2013.06.009, in press, 2013.

D’Anjou, R. M., Wei, J. H., Castañeda, I. S., Brigham-Grette, J., Petsch, S. T., and Finkelstein, D. B.: High-latitude environmental change during MIS 9 and 11: biogeochemical evidence from Lake El'gygytgyn, Far East Russia, Clim. Past, 9, 567-581, doi:10.5194/cp-9-567-2013, 2013.

Davison, W.: Iron and manganese in lakes, Earth Sci. Rev., 34, 119_ $163,1993$.

EPICA Community Members: Eight glacial cycles from an Antarctic ice core, Nature, 429, 623-628, 2004.

Francke, A., Wennrich, V., Sauerbrey, M., Juschus, O., Melles, M., and Brigham-Grette, J.: Multivariate statistic and time series analyses of grain-size data in Quaternary sediments of Lake El'gygytgyn, NE Russia, Clim. Past Discuss., 9, 217-244, doi:10.5194/cpd-9-217-2013, 2013.

Frank, U., Nowaczyk, N. R., Minyuk, P., Vogel, H., Rosén, P., and Melles, M.: A $350 \mathrm{kyr}$ record of climate change from Lake El'gygytgyn, Far East Russian Arctic: refining the pattern of climate modes by means of cluster analysis, Clim. Past Discuss., 8, 5109-5132, doi:10.5194/cpd-8-5109-2012, 2012.

Gebhardt, A. C., Niessen, F., and Kopsch, C.: Central ring structure identified in one of the world's best-preserved impact craters, Geology, 34, 145-148, 2006.

Geladi, P., MacDougall, D., and Martens, H.: Linearization and scatter-correction for near-infrared reflectance spectra of meat, Appl. Spectrosc., 39, 491-500, 1985.

Glotov, V. Ye. and Zuev, S. A.: Hydrological characteristics of Lake El'gygytgyn, Kolyma, 3-4, 18-23, 1995.

Glushkova, O. Yu. and Smirnov, V. N.: Pliocene to Holocene geomorphic evolution and paleogeography of the El'gygytgyn Lake region, NE Russia, J. Paleolimnol., 37, 37-47, 2007.
Imbrie, J., Hays, J. D., Martinson, D. G., Mc lntyre, A., Mix, A. C., Morley, J. J., Pisias, N. G., Prell, W. L., and Shackleton, N. J.: The orbital theory of Pleistocene climate: support from a revised chronology of the marine $118 \mathrm{O}$ record, in: Milankovitch and Climate, Part I, edited by: Berger, A. L., 269-305, Reidel Publishing Company, Dordrecht, Netherlands, 1984.

Imbrie, J., Berger, A., Boyle, E. A., Clemens, S. C, Duffy, A, Howard, W. R., Kukla, G., Kutzbach, J., Martinson, D. G., Mclntyre, A, Mix, A. C., Molfino, B., Morley, J. J., Peterson, L. C, Pisias, N. G., Prell, W. L., Raymo, M. E., Shackleton, N. J., and Toggweiler, J. R.: On the structure and origin of major glaciation cycles 2 . The origin of 100,000 - year cycle, Paleoceanography, 8, 699-735, 1993.

IPCC, 2007: Climate Change 2007: The Physical Science Basis. Contribution of Working Group I to the Fourth Assessment Report of the Intergovernmental Panel on Climate Change edited by: Solomon, S., Qin, D., Manning, M., Chen, Z., Marquis, M., Averyt, K. B., Tignor, M., and. Miller, H. L., Cambridge University Press, Cambridge, United Kingdom and New York, NY, USA, 996 pp., 2007.

Jouzel, J., Masson-Delmotte, V., Cattani, O., Dreyfus, G., Falourd, S., Hoffmann, G., Minster, B., Nouet, J., Barnola, J. M., Chappellaz, J., Fischer, H., Gallet, J. C., Johnsen, S., Leuenberger, M., Loulergue, L., Luethi, D., Oerter, H., Parrenin, F., Raisbeck, G., Raynaud, D., Schilt, A., Schwander, J., Selmo, E., Souchez, R., Spahni, R., Stauffer, B., Steffensen, J.P., Stenni, B., Stocker, T. F., Tison, J. L., Werner, M., and Wolff, E.: Orbital and millennial Antarctic climate variability over the past 800,000 years, Science, 317, 793-796, 2007.

Juschus, O., Melles, M., Gebhardt, A. C., and Niessen, F.: Late Quaternary mass movement events in Lake El'gygytgyn, NorthEastern Siberia, Sedimentology, 56, 2155-2174, 2009.

Kandiano, E. S. and Bauch, H. A.: Phase relationship and surface water mass change in the NorthEast Atlantic during Marine Isotope stage 11 (MIS 11), Quaternary Res., 68, 445-455, 2007.

Kandiano, E. S., Bauch, H. A., Fahl, K., Helmke, J. P., Röhl, U., Pérez-Folgado, M., and Cacho, I.: The meridional temperature gradient in the eastern North Atlantic during MIS 11 and its link to the ocean-atmosphere system, Palaeogorgr. Palaeoclimat. Palaeoecol., 333-334, 24-39, 2012.

Karabanov, E. B., Prokopenko, A. A., Williams, D. F., Khursevich, G. K., Kuzmin, M. I., Bezrukova, E. V., and Gvozdkov, A. N.: High-resolution MIS 11 record from the continental sedimentary archive of Lake Baikal, Siberia, in: Earth's Climate and Orbital Eccentricity: The Marine Isotope Stage 11., edited by: Droxler, A., Poore, R., and Burckle, L., American Geophysical Union, Washington, 223-230, 2003.

Laskar, J., Robutel, P., Joutel, F., Gastineau, M., Correia, A. C. M., and Levrard, B.: A long-term numerical solution for the insolation quantities of the Earth, Astron. Astrophys., 428, 261-285, 2004.

Layer, P. W.: Argon-40/argon-39 age of the El'gygytgyn impact event, Chukotka, Russia, Meteor. Planet. Sci., 35, 591-599, 2000.

Li, L., Qianyu, L., Jun, T., Pinxian, W., Hui, W., and Zhonghui, L.: A 4-Ma record of thermal evolution in the tropical western Pacific and its implications on climate change, Earth Planet. Sci. Lett., 309, 10-20, 2011. 
Lisiecki, L. E. and Raymo, M. E.: A Pliocene-Pleistocene stack of 57 globally distributed benthic $\delta^{18} \mathrm{O}$ records, Paleoceanography, 20, PA1003, doi:10.1029/2004PA001071, 2005.

Loulergue, L., Schilt, A., Spahni, R., Masson-Delmotte, V., Blunier, T., Lemieux, B., Barnola, J.-M., Raynaud, D., Stocker T. F., and Chappellaz, J.: Orbital and millennial-scale features of atmospheric $\mathrm{CH}_{4}$ over the past 800,000 years, Nature, 453, 383-386, 2008.

Loutre, M. F. and Berger, A.: Future climatic changes: are we entering an exceptionally long interglacial?, Clim. Change, 46, 61-90, 2000.

Loutre, M. F. and Berger, A.: Marine Isotope Stage 11 as an analogue for the present interglacial, Global Planet. Change, 36, 209-217, 2003.

Lozhkin, A. V. and Anderson, P. M.: Vegetation responses to interglacial warming in the Arctic: examples from Lake El'gygytgyn, Far East Russian Arctic, Clim. Past, 9, 1211-1219, doi:10.5194/cp-9-1211-2013, 2013.

Martens, H. and Næs, T.: Multivariate Calibration, John Wiley \& Sons, Chichester, New York, Brisbane, Toronto, Singapore, 1989.

Martrat, B., Grimalt, J. O., Shackleton, N. J., de Abreu, L., Hutterly, M. A., and Stocker, T. F.: Four climate cycles of recurring deep and surface water destabilizations on the Iberian margin, Science, 317, 502-507, 2007.

McManus, J. F., Oppo, D. W., and Cullen, J. L.: A 0.5-millionyear record of millennial-scale climate variability in the North Atlantic, Science, 283, 971-975, 1999.

Melles, M., Brigham-Grette, J., Glushkova, O. Y., Minyuk, P. S., Nowaczyk, N. R., and Hubberten, H. W.: Sedimentary geochemistry of core PG1351 from Lake El'gygytgyn - a sensitive record of climate variability in the East Siberian Arctic during the past three glacialinterglacial cycles, J. Paleolimnol., 37, 89-104, 2007.

Melles, M., Brigham-Grette, J., Minyuk, P., Koeberl, C., Andreev, A., Cook, T., Fedorov, G., Gebhardt, C., Haltia-Hovi, E., Kukkonen, M., Nowaczyk, N., Schwamborn, G., Wennrich, V., and and the El'gygytgyn Scientific Party: The Lake El'gygytgyn Scientific Drilling Project - Conquering Arctic Challenges through Continental Drilling, Scientific Drilling, 11, 29-40, 2011.

Melles, M., Brigham-Grette, J., Minyuk, P. S., Nowaczyk, N. R., Wennrich, V., DeConto, R. M., Anderson, P. M., Andreev, A. A., Coletti, A., Cook, T. L., Haltia-Hovi, E., Kukkonen, M., Lozhkin A. V., Rosén, P., Tarasov, P., Vogel, H., and Wagner, B.: 2.8 million years of Arctic climate change from Lake El'gygytgyn, NE Russia, Science, 337, 315-320, 2012.

Meyer-Jacob, C., Vogel, H., Melles, M., and Rosén, P.: Biogeochemical properties and diagenetic changes during the past 3.6 Ma recorded by FTIR spectroscopy in the sediment record of Lake El'gygytgyn, Far East Russian Arctic, Clim. Past Discuss., 9, 2489-2515, doi:10.5194/cpd-9-2489-2013, 2013.

Meyers, P. A. and Ishiwatari, R.: Lacustrine organic geochemistry - an overview of organic matter sources and diagenesis in lake sediments, Org. Geochem., 20, 867-900, 1993.

Mottaghy, D., Schwamborn, G., and Rath, V.: Past climate changes and permafrost depth at the Lake El'gygytgyn site: implications from data and thermal modeling, Clim. Past, 9, 119-133, doi:10.5194/cp-9-119-2013, 2013.
Nolan, M. and Brigham-Grette, J.: Basic hydrology, limnology, and meteorology of modern Lake El'gygytgyn, Siberia, J. Paleolimnol., 37, 17-35, 2007.

Nolan, M., Liston, G., Prokein, P., Brigham-Grette, J., Sharpton, V. L., and Huntzinger, R.: Analysis of lake ice dynamics and morphology on Lake El'gygytgyn, NE Siberia, using synthetic aperture radar (SAR) and Landsat, J. Geophys. Res. Atmos., 108, 8162, doi:10.1029/2001JD000934, 2002.

Nowaczyk, N. R., Minyuk, P., Melles, M., Brigham-Grette, J., Glushkova, O. Yu., Nolan, M., Lozhkin, A. V., Stetsenko, T. V., Andersen, P. M., and Forman, S. L.: Magnetostratigraphic results from impact crater lake El'gygytgyn, Northeastern Siberia: a possibly $300 \mathrm{kyr}$ long terrestrial paleoclimate record from the Arctic, Geophys. J. Int., 150, 109-126, 2002.

Nowaczyk, N. R., Haltia, E. M., Ulbricht, D., Wennrich, V., Sauerbrey, M. A., Rosén, P., Vogel, H., Francke, A., Meyer-Jacob, C., Andreev, A. A., and Lozhkin, A. V.: Chronology of Lake El'gygytgyn sediments, Clim. Past Discuss., 9, 3061-3102, doi:10.5194/cpd-9-3061-2013, 2013.

Olson, S. L. and Hearty, P. J.: A sustained $21 \mathrm{~m}$ sea-level highstand during MIS 11 (400 ka): direct fossil and sedimentary evidence from Bermuda, Quaternary Sci. Rev. 28, 271-285, 2009.

Oppo, D. W., McManus, J. F., and Cullen, J. L.: Abrupt climate events 500,000 to 340,000 years ago: Evidence from subpolar North Atlantic sediments, Science, 279, 1335-1338, 1998.

Pol, K., Debret, M., Masson-Delmotte, V., Capron, E., Cattani, O., Dreyfus, G., Falourd, S., Johnsen, S., Jouzel, J., Landais, A., Minster, B., and Stenni, B.: Links between MIS 11 millennial to sub-millennial climate variability and long term trends as revealed by new high resolution EPICA Dome $\mathrm{C}$ deuterium data - A comparison with the Holocene, Clim. Past, 7, 437-450, doi:10.5194/cp-7-437-2011, 2011.

Prokopenko, A. A., Karabanov, E. B., Williams, D. F., Kuzmin, M. I., Khursevich, G. K., and Gvozdkov, A. A.: The detailed record of climatic events during the past 75,000 yrs BP from the Lake Baikal drill core BDP-93-2, Quaternary Int., 80-81, 59-68, 2001.

Prokopenko, A. A., Bezrukova, E. V., Khursevich, G. K., Solotchina, E. P., Kuzmin, M. I., and Tarasov, P. E.: Climate in continental interior Asia during the longest interglacial of the past 500000 years: the new MIS 11 records from Lake Baikal, SE Siberia, Clim. Past, 6, 31-48, doi:10.5194/cp-6-312010, 2010.

Raymo, M. E. and Mitrovica, J. X.: Collapse of polar ice sheets during the stage 11 interglacial, Nature, 483, 453-456, 2012.

Raynaud, D., Barnola, J.-M., Souchez, R., Reginald, L., Petit, J.-R., Duval, P., and Lipenkov, V. Y.: Paleoclimatology: The record for marine isotopic stage 11, Nature, 436, 39-40, 2005.

Rosén, P., Vogel, H., Cunningham, L., Hahn, A., Hausman, S., Pientiz, R., Wagner, B., and Persson, P.: A globally applicable model for quantitative determination of lake sediment properties using Fourier transform infrared spectroscopy, Environ. Sci. Technol., 45, 8858-8865, 2011.

Schaefer, G., Rodger, J. S., Hayward, B. W., Kennett, J. P., Sabaa, A. T., and Scott, G. H.: Planktic foraminiferal and sea surface temperature record during the last $1 \mathrm{Myr}$ across the Subtropical Front, Southwest Pacific, Mar. Micropal., 54, 191-212, 2005.

Schwamborn, G., Fedorov, G., Schirrmeister, L., Meyer, H., and Hubberten, H. W.: Periglacial sediment variations controlled by late Quaternary climate and lake level change at Elgygytgyn 
Crater, Arctic Siberia, Boreas, 37, 55-65, 2008.

Siegenthaler, U., Stocker, T. F., Monnin, E., Lüthi, D., Schwander, J., Stauffer, B., Raynaud, D., Barnola, J.-M., Fischer, H., Masson-Delmotte, V., and Jouzel J.: Stable Carbon CycleClimate Relationship During the Late Pleistocene, Science, 310, 1313-1317, 2005.

Sirocko, F., Seelos, K., Schaber, K., Rein, B., Dreher, F., Diehl, M., Lehne, R., Jager, K., Krbetschek, M., and Degering, D.A.: Late Eemian aridity pulse in central Europe during the Last Glacial Inception, Nature, 436, 833-836, 2005.

Snyder, J. A., Cherepanova, M. V., and Bryan, A.: Dynamic diatom response to changing climate $0-1.2 \mathrm{Ma}$ at Lake El'gygytgyn, far east Russian Arctic, Clim. Past Discuss., 8, 4601-4624, doi:10.5194/cpd-8-4601-2012, 2012.

Treshnikov, A. F.: Atlas of the Arctic, Main Department of Geodesy and Cartography under the Council of Ministers of the USSR, Moscow, 1985.

Vogel, H., Rosén, P., Wagner, B., Melles, M., and Persson, P.: Fourier transform infrared spectroscopy, a new cost-effective tool for qualitative analysis of biogeochemical properties in long sediment records, J. Paleolimnol., 40, 689-702, 2008.
Wennrich, V., Minyuk, P., Borkhodoev, V., Francke, A., Ritter, B., Nowaczyk, N., Haltia-Hovi, E. M., Brigham-Grette, J., Melles, M., and El'gygytgyn Scientific Party: Pliocene and Pleistocene climate and environmental history of Lake El'gygytgyn/NE Russia based on high-resolution inorganic geochemistry data, Clim. Past, in preparation, 2013.

Willerslev, E., Cappellini, E., Boomsma, W., Nielsen, R., Hebsgaard, M. B., Brand, T. B., Hofreiter, M., Bunce, M., Poinar, H. N., Dahl-Jensen, D., Johnsen, S., Steffensen, J. P., Bennike, O., Schwenninger, J.-L., Nathan, R., Armitage, S., de Hoog, C.-J., Alfimov, V., Christl, M., Beer. J., Muscheler, R., Barker, J., Sharp, M., Penkman, K. E. H., and Haile, J.: Ancient biomolecules from deep ice cores reveal a forested Southern Greenland, Science, 317, 111-114, 2007. 